\title{
DEVELOPING TEACHING MATERIAL FOR INDONESIAN LANGUAGE EDUCATION BASED ON SCIENTIFIC LEARNING TO ENHANCE STUDENTS' CREATIVITY AND INNOVATION
}

\author{
Abd. Hafid ${ }^{1}$, Rosmalah ${ }^{2}$, Rukayah $^{3}$ \\ \{hafidabdul196403@gmail.co.id $\left.{ }^{1}\right\}$ \\ ${ }^{1,2,3}$ Primary Teacher Education, Faculty of Education, Universitas Negeri Makassar, \\ Makassar, Indonesia
}

\begin{abstract}
Creativity and innovation in Indonesian Language Education for Primary School Teacher Education students in State University of Makassar needs to be developed. When conducting scientific learning activities, it is necessary to develop teaching material that can enhance students' creativity and innovation. This requires scientific-based teaching materials that can be used in learning. The formulation of the problem in this research is (1) Can scientificbased teaching materials be able to foster creativity and innovation in learning Indonesian Language Education for PGSD students in UNM? (2) are scientific based teaching materials effectively used to foster students' creativity and innovation? The research objective is to develop teaching materials for Indonesian language education based on scientific learning and to foster PGSD students' creativity and innovation. The research used Quantitative research approach with the type of research development. This research involved 20 students in the sixth semester. Test and observation were used as research instruments. Data analysis technique used was descriptive analysis. The results of the study showed that the creativity and innovation of students in Indonesian Language Education courses based on scientific learning showed very good category. The results of the analysis on the effectiveness and the efficiency of the teaching materials based on students' achievement on scientific based learning materials were in the Very Good category. It can be concluded that scientificbased Indonesian language teaching materials can assist lecturers in carrying out the teaching process that can foster PGSD students' creativity and innovation in State University of Makassar.
\end{abstract}

Keywords: Teaching Materials, Scientific Learning 


\section{Introduction}

Indonesian language is a unifying language for the Republic of Indonesia. This language can be considered as simple or complex. Indonesian language can be considered easy, especially for Indonesian, because they use it everyday, however it can be considered tricky when searching to all aspects of the subjects. Through Indonesian language education, students are directed to feel proud to be Indonesian citizens and to show love for their motherland. Indonesian language education subject for PGSD students is specifically designed to develop knowledge and understanding of the importance of Indonesia, in order to develop values / attitudes to make changes for students in elementary school in the future to become a generation that can compete internationally.

Based on the report of the United Nations Development Program (UNDP) in March 2013 Indonesia ranked 121 out of 185 countries. This data covers aspects of labor, health, and education. Indonesia has increased in rank compared to the previous year (ranking 124 out of 187 countries in 2012). This position places Indonesia in the middle class. Indonesia's score of 0.684 , or still below the world average of 0.702 . Indonesia's ranking is still below the world average and below the four countries in the ASEAN region (Singapore, Brunei, Malaysia and Thailand).

In addition, the Program Results for International Student Assessment (PISA) 2012, Indonesia ranked 64th out of 65 countries participating in the test. Indonesia is only slightly better than Peru, which is ranked to be the lowes 1 average math scores of Indonesian children were 375 , the average reading score was _... $1, . . \mathrm{d}$ the average score for science was 382. In fact, the average scores were 494, 496, and 501, respectively.

After considering Indonesian students' position and achievement compared to the achievements of students from other countries and the factors that influence it, it is necessary to formulate appropriate policies and implementation strategies to improve Indonesia's competitiveness and excellence. One problem that arises in the development of knowledge and understanding of the emphasis on the level of achievement obtained by Indonesian children that needs to be formulated. The root of the problem is the learning system which emphasizes students to be smart but the emphasis on teachers or prospective educators is ignored. Therefore, before students are demanded to be smart, the teacher or prospective teacher must be smart to be able to implement good methods in teaching and learning process as well as the subject mastery to be taught.

Based on the activities of teachers who always provide lecture and assignment methods, students can only obtain theoretical lessons without getting quality learning. As mandated in Law Number 20 Year 2003 concerning the National Education System that education is a conscious and planned effort to create an atmosphere of learning and learning process so that students actively develop their potential to have religious spiritual strength, self-control, personality, intelligence, morals, as well as the skills needed by himself, society, nation and state. Based on this, the question that arises is "what can be done about it?"

Answering the question above, it takes the ability of students, namely the ability to recognize, examine information and give thoughts / information by providing learning activities that can change the learning paradigm of conventional learning that is only done in class. Changing the conventional paradigm to innovative learning activities can activate students through scientific-based learning by using various learning resources and the environment as a source of information. Sources of information in learning can be teaching materials that are applied according to scientific learning with five activities namely 
observing, asking questions, conducting experiments or seeking information, and communicating the results of investigations.

One of the efforts that can be done is to equip the prospective educators with the knowledge of developing teaching materials as in accordance with lesson plan. The form of teaching materials considered to be capable of meeting the learning outcome is scientificbased learning. The teaching material is Indonesian language teaching material of scientific based 2013 curriculum that are in accordance with scientific learning steps.

\section{Literature Review}

\subsection{Definition of Scientific}

The increasingly rapid development of science and technology which requires an attitude of being ready to obtain information that is increasingly unavoidable so that the tools needed to obtain information are none other than language as a means of communication at the national or international level. In this case, Indonesia has a unifying language and at the same time obtaining information at the national level, namely Bahasa Indonesia. The learning of Indonesian language is inseparable from the material that has been formulated in the curriculum. This is useful in providing directed learning flow according to the level of students' thinking abilities.

One of the learning processes in the implementation of the 2013 curriculum in Elementary Schools, a teacher must use a scientific approach because this approach is more effective and efficient in achieving applicable curriculum objectives, especially the 2013 curriculum. Kosasi (2016: 125) states that "Scientific learning is a learning that prioritizes students' creativity and innovation ". In line with Barriger (Abidin, 2016: 125)" Scientific learning is a learning that requires students to think systematically and critically in an effort to solve problems in which the solutions are not easily seen ".

Based on expert opinion, it can be concluded that scientific learning is a learning that emphasizes students' activities in obtaining information on a regular basis and is a form of students' creativity in obtaining or creating their own ideas. Processes happen factually in a conceptual framework that is useful for re-organizing and maintaining new information or ideas. Scientific learning can also be linked to Bloom's taxonomy which consists of three domains, namely attitudes, knowledge, and skills. In the learning process that is based on a scientific approach, the realm of attitude takes the transformation or teaching material of students to "Know why", meaning why learning is done. What is the goal of developing or improving attitudes that need to be outlined in learning. The realm of knowledge embraces the transformation of substance or teaching material so that students know contextual knowledge that needs to be emphasized in the material. The realm of skills means the level of creativity adapted to the process of generating ideas. This can be described as follows:

The final result in learning is an increase and balance between the ability to become a better human being (Soft Skills) and humans who have the skills and knowledge to live properly (Hard Skills) for students including some aspects of competence in attitudes, skills, and knowledge so that the teacher becomes a professional who is able to inspire students to improve and develop the realm of attitude, knowledge, and skills. The domains developed can be a means of forming effective education.

Language skills development is carried out by developing cognitive abilities, analysis, synthesis, evaluation, and creation through a direct study of social conditions by using the ability to think carefully and critically. Students' understanding of social phenomena with direct recognition will make it easier for students to develop their competencies. Students 
must be familiar with reading various information and accessing information from electronic and written media. In addition, they need to follow the development of civilization that is happening factually. Therefore, learning Indonesian language is considered necessary to apply a scientific approach.

The scientific approach includes five aspects, namely: (1) observing, (2) asking, (3) reasoning, (4) associating, and (5) communicating. Observing activities aim at obtaining a general description of a material object with regard to the basic competencies learned, such as presenting the media in real terms. The questioning activity aims at students having high-level thinking skills critically, logically, and systematically. Reasoning is the process of thinking systematically on empirical facts that can be observed to obtain results or conclusions. Associating refers to applying, developing and deepening understanding of a concept to other similar concepts, while communicating is a means of conveying the results of activities to others verbally and in written form.

Based on the description above, it can be said that the scientific approach is a learning approach that can create learning activities leading students to have creativity and innovation skills in science that can be applied in everyday life.

\subsection{Indonesian Language Learning}

Indonesian language is a communication tool used by the community for daily use. Indonesian language is a change in behavior that is relatively permanent and is the result of language training that is strengthened. Language learning is a long and complex endeavor involving the whole body and soul when learning a language. Comprehensive involvement and ongoing concern either physical, intercultural, or emotional are necessary to master the language.

Indonesian language learning will succeed if the teacher adapts the learning approach to the students' abilities. These adjustments must be well designed with the aim of preparing students for meaningful interactions in natural language environment. Interaction can be meaningful for students if Indonesian language learning is designed appropriately. Designing Indonesian language lesson plan is directed towards students as learning subjects. Through learning experiences, students find, apply, analyze, compare, arrange, refine, assess, and conclude the subject matter they have learned.

Student learning experiences are behavioral changes in capacity that are relatively permanent as a result of experience. Learning is a relative and continuous process through a variety of experiences. According to Gagne, Briggs, and Wager (Harjanto, 2003: 23) in the learning process, there are various conditions that can determine learning outcomes. Factors that influence learning success are conditions related to the learning process, namely external conditions and internal conditions.

\subsection{Understanding Indonesian Language Teaching Materials}

Teaching materials are "all forms of materials used to assist teachers in implementing the teaching and learning activities" the Ministry of National Education (2008: 6). The teaching material can be either written or unwritten. Furthermore Prastowo (2012) states that teaching materials are all materials either information, tools, or texts that are arranged systematically to display competencies that will be mastered by students and used in the learning process with the aim of implementing the lesson plan.

Based on the definition of teaching materials, teaching materials contain facts, concepts, principles and procedures that are relevant and written in the form of items in accordance with 
the formulation of indicators and competency achievement. According to Akbar (2016: 30) learning material has an important role in learning, including integrated learning. Therefore integrated learning is the integration of various disciplines that cover the natural sciences thus learning requires teaching materials that are more complete and comprehensive than monolithic learning. Development of teaching materials according to Nunan (1991: 86) is the process of selecting, adapting, and making teaching materials based on certain framework references. This is the importance of teaching materials, especially learning design.

According to Gagne, Briggs, and Wager (Harjanto, 2003: 23) the objectives of teaching materials are as follows.

a. Helps students to learn individually

b. Provide flexibility in the presentation of short-term and long-term learning.

c. The design of systematic teaching materials has a great influence on the development of individual human resources.

d. Facilitating the management of the learning process with a systemic approach.

e. Easy to learn, because it is designed on the basis of knowledge of how humans learn

The principles of developing teaching materials according to the Ministry of National Education (2008: 12), namely:

a. Starting from the easy to understand the difficult, from the concrete to understand the abstract.

b. Repetition will strengthen understanding.

c. Positive feedback will strengthen students' understanding.

d. High learning motivation is one of the determining factors for learning success.

e. Reaching the goal is like climbing stairs, step by step, eventually reaching a certain height.

f. Knowing the results will encourage students to continue to achieve goals.

Based on the expert opinion above, it can be concluded that teaching materials are all forms of materials used to assist teachers in carrying out teaching and learning activities. The materials may be written or unwritten and are used to achieve the learning goals.

\subsection{Teachers' Creativity and Learning Innovation}

The definition of creativity proposed by Suryosubroto (Monawati, 2018) is the ability to create a new product or a modification or change by developing things that already exist. Creativity is also understood as the ability to create, change, and develop ideas, processes, products, modes, models, and services as well as certain behaviors and contains the characteristics of authenticity (new, unusual, unpredictable) and potential strategies for increasing human resources, school policy or introduction of teacher team work in specific fields (Rusdiana and Heryati, 2015).

Educative learning will take place well if the conditions and learning atmosphere enable students to be actively and proactively involved, meaning that the conditions and learning atmosphere will be created if a number of learning experiences have been designed to be done by students (Lapono et al., 2009). Quality learning experiences will be obtained by students from the creativity of a teacher in the learning process thus creative teachers are important. Being creative is a condition when someone has the ability to create. Someone who has a high level of creativity is called creative ability or having high creativity. The innovative nature is renewal or new creation. This creation can be related to approaches, methods, or ideas. In other words innovative means the ability to introduce something new (Rusdiana and Heryati, 2015). 
Classroom learning is an essential process of communication between teacher and tudents. Therefore, subjects involved in the process must be prepared to accept each other's personal conditions (Suyanto and Jihad, 2013). Thus professional teachers are able to create conducive and interesting learning as well as to create multi-directional learning by recognizing student personalities. This will be created through teachers' creativity because from that creativity the teacher can be said to be professional.

Rusdiana and Heryati (2015) suggested that, it is not difficult to be a creative teacher if they have fulfilled the following requirements: (1) selection of learning methods / approaches (use of science and technology) that are in accordance with the topic of discussion. The method applied must be interesting so that students do not get bored, for example using LCD in the classroom so that all material is delivered to students, (2) the teacher and students must also actively ask each other questions so that the class atmosphere seems alive. (3) creation and use of learning facilities. The design of learning experiences can be improvised by utilizing the potential of the region as a learning medium, for example by using used items such as bottled water, stereofoam into a water rocket that shows creativity and innovation, (4) class and / or laboratory management in accordance with the method / the approach chosen can change the atmosphere of learning. The position of the U or V-shaped table / chair is very suitable for demonstration and discussion methods. The sitting position of students facing each other without changing the position of the chair is effective for group work. The sitting position can be adjusted according to the method being applied. According to Suyanto and Jihad (2013), to become professional and creative teachers, teachers must create a conducive learning experience through the use of instructional media, as well as providing a variety of methods, classroom management, and good learning resources.

\subsection{Learning Innovation}

According to Barlian (2013: 75), innovation comes from the words latin in and novus, which means renewal and change. Innovation is a new change towards improvement which is certainly different from the one that already existed before. Innovation is needed in the world of education to adjust the development of science and technology. With innovative and conducive learning, overall students are not bored with monotonous learning methods. In line with this, Rusdiana and Heryati (2015) suggested that, to be an innovative and conducive, teacher must master the material before teaching. The subject matter needs to be prepared by teachers by considering the characteristics and abilities of their students. A teacher must process subject matter in a logical order, which can be taught (teachable) and accepted (accessible).

\section{Method}

The research is qualitative with the type of research development conducted by lecturers in the form of a team to design teaching material units based on experience, potential, and existing conditions by conducting trials. This trial activity is accompanied by an evaluation and reflection process in order to accomplish. The location of the study was Primary School Teacher Education Study Program (PGSD) in the sixth campus of State University of Makassar. Research subjects were students who programed Indonesian Language courses in the study program. The procedure of conducting research follows the Four-D Development Model (Thiagarajan, et al, 1974) which consists of four stages, namely defining, designing, developing, and disseminating. The learning validation sheet was used to obtain data about the results of experts and practitioners validations namely, observation sheet of students' 
activities, observation sheet of lecturers' activity, observation sheet of the implementation of the teaching material. Data on students' responses to the field trial activities were obtained through students' questionnaire responses. While the level of students' mastery towards learning material that has been taught is intended as a main indicator to measure the effectiveness of learning media.

The results of experts and practitioners validation for each component of the model were then analyzed by considering input, comments, suggestions and criticisms from various parties. The next assessment was carried out by observing the learning process for each meeting. Analysis of observations on students' activities includes: (1) the average frequency of each activity category for each meeting, (2) the percentage of each student's activity category for each meeting, and (3) the average category of students' activity for all meetings. The activities that were carried out were as follows; (1) recapitulate the observations of the implementation of learning material, (2) find the average of each aspect of observation in each meeting, (3) find the average of each observation aspect for one meeting, (4) find the total mean $(\bar{X})$, and (5) determine the implementation categories of each aspect or all aspects by matching the average of each aspect or the total average with the predetermined categories.

The steps taken related to data analysis; (1) count the number of students who give positive responses according to the aspects asked, then calculate the percentage, (2) determine the categories for students' positive responses by matching the percentage results with established criteria, and (3) if the results of the analysis show that the response of students has not been positive, a revision of the teaching material being developed. The basic score for the next meeting is taken from the average base score in several previous meetings. Quantitative data used descriptive statistics. While qualitative data were analyzed using the technique of analyzing data analysis by Miles and Huberman (2007).

\section{Research Results}

\section{Results of Analysis on the Feasibility of Teaching Materials}

The results of the analysis on the feasibility level of teaching materials have been made after being examined and viewed by experts or Indonesian language. Furthermore, the criteria for the level of validity of the learning materials used in this study are the validity codes as follows:

Value $4,5 \leq \bar{V} \leq 5 \quad$ Very Valid (VV)

\begin{tabular}{ll}
\hline Value $3,5 \leq \bar{V}<4,5$ & Valid (V) \\
\hline Value $2,5 \leq \bar{V}<3,5$ & Average Level (AL) \\
\hline Value $2,5 \leq \bar{V}<3,5$ & Less Valid (LV) \\
\hline Value $\bar{V}<1,5$ & Not Valid (NV)
\end{tabular}

\section{Results of Analysis on the Validity Level of Teaching Materials}

The average value of the validity level on teaching materials is $=3.9$. Thus, it can be concluded that the average value is in the category of "Valid". In other words, it is included in the range $(3.5 \leq \bar{V}<4,5)$. If viewed from all aspects of the criteria, then the students' book is considered to meet valid criteria. The score of each aspect required a textbook that meets the 
criteria as follows; First, the average value of the validity level for aspects of the format is $\bar{V}=$ 3.8. Thus, it can be concluded that the value is included in the Valid category. In other words, including in the interval $(3.5 \leq \bar{V}<4.5)$. In terms of format, the textbook was declared to meet a valid category. Second, the average value of the validity level for language aspects is $\bar{V}=4.2$. Thus, it can be concluded that the value is included in the Valid category, in other words, included in the interval $(3.5 \leq \bar{V}<4.5)$. Judging from the aspect of language, the textbook was declared to meet a valid category. Third, the average value of the validity level for the illustration aspect is $\bar{V}=4.1$. Thus, it can be concluded that the value is included in the Valid category, in other words, included in the interval $(3.5 \leq \bar{V}<4.5)$. Judging from the aspect of illustration, the teaching material is declared to meet the valid category. Fourth, the average value of the level of validity for the Content aspect is $\bar{V}=4.0$. Thus, it can be concluded that the value is included in the Valid category, in other words, included in the interval $(3.5 \leq$ $\bar{V}<4.5)$. Judging from the aspect of content, the teaching material is declared to meet valid categories.

\section{Results of Analysis on the Effectiveness of Teaching Materials}

\subsection{Data Analysis Results on the Observation of Students' Response.}

Based on data about average percentage of students' responses from three observers, information was obtained that students were more active in doing activities in the first category, namely Listening / paying attention to lecturers' explanations actively. Then followed by the seventh and fifth categories in a row namely responding to friends' answers or expressing opinions / ideas and compare answers and discuss in their cooperative groups. This is because the learning model used is a cooperative learning model so students are required to work together in groups and exchange ideas to solve problems in daily life. In addition, the format of teaching materials that are made is equipped with interactive questions to make students interested and motivated to follow the learning process. In addition, the results of the analysis show that all categories are within the intervals of ideal time tolerance during the learning process. Specifically for categories (1), (4), (6), and (7) which are categories that must be met, the average value obtained is almost exactly the same as the ideal time that has been determined.

\subsection{Data Analysis Results on the Observation of Lecturer Activity}

The average value of the total lecturers' activity obtained is $(\bar{V})=4.6$. Thus it can be concluded that the value is in the "Very Good" category with intervals $(4.5 \leq \bar{V} \leq 5)$ of the ideal score. So, in terms of all aspects of the lecturers' activities, they are categorized as effective in learning activities. Furthermore, the results of the analysis for each aspect can be explained as follows: First, the average value of lecturers' activity for the initial aspect of the activity is $\bar{V}=4.4$. Thus it can be concluded that the value is included in the category of "Good" with intervals $(4.5 \leq \bar{V} \leq 5)$ of an ideal score of 5 . So, in terms of aspects of the initial activities of the lecturer activities, then categorized as effective in learning activities. Second, the average value of lecturers' activity for aspects of core activities is $\bar{V}=4.6$. Thus it can be concluded that the value is included in the category of "Very Good" with intervals $(4.5 \leq \bar{V} \leq$ 5) of an ideal score of 5. So, in terms of aspects of the core activities of the lecturers' activities, they are categorized as effective in learning activities. Third, the average value of lecturers' activity for the final activity aspect is $\bar{V}=4.6$. Thus it can be concluded that the value is included in the category of "Very Good" with intervals $(4.5 \leq \bar{V} \leq 5)$ of an ideal score of 5 . So, in terms of the final activity aspects of the lecturers' activities, they are considered effective in 
learning activities. Fourth, the average value of lecturer activity for the aspect of time management is $\bar{V}=4.6$. Thus it can be concluded that the value is included in the category of "Very Good" with intervals $(4.5 \leq \bar{V} \leq 5)$ of an ideal score of 5. So, in terms of time management aspects of lecturer activities, it is categorized as effective in learning activities, and fifth, the average value of lecturer activity for aspects of classroom atmosphere is $\bar{V}=4.6$. Thus it can be concluded that the value is included in the category of "Very Good" with an interval $(4.5 \leq \bar{V} \leq 5)$ of an ideal score of 5 . So, in terms of the classroom atmosphere aspects of the lecturer activities, it is categorized as effective in learning activities.

\subsection{Data Analysis Result of the Observation of the Implementation of Teaching Materials}

The analysis results of the analysis on the implementation of the learning or teaching materials in the table above can be explained as follows:

Overall, the observer generally observes that the learning media used are available and the teaching materials are also implemented or used quite well and can even be said to be quite perfect.

Then specifically all aspects can be explained as follows: first, the syntax aspect, in general the observer sees that the syntax of the learning media used is "available" and the teaching material is implemented or used quite well and can even be said to be quite perfect. Second, the aspect of the social system, in general the observer sees that the social system of teaching materials used is "available" and the learning device is implemented or used quite well and can even be said to be quite perfect. Third, aspects of the support system, in general the observer sees that the support system of the learning media used is "available" and the learning media is implemented or used quite well and can even be said to be quite perfect.

\subsection{Data Analysis Result on the Efficiency Levels of Teaching Materials Based on Student Achievement Review}

The results of the descriptive statistics analysis and their representation in the development of Indonesian language teaching materials in high classes have shown that these teaching materials are very effective for use in lectures. This shows that the average score of students from pre-test to post-test has increased (from 2.75 to 3.50). The average score of students in the pre-test was 2.75 with a standard deviation of 0.94 , a minimum value of 0 (E) and a maximum value of 4 (A) of an ideal score of 4 . Meanwhile, the average score of students at posttest was 3.50 with a standard deviation of 0.33912 , a minimum value of 2.8 and a maximum of 3.8 from an ideal score of 4 . The increase shows that teaching materials that have been prepared in Indonesian language courses in higher education that are used in lectures on PGSD study programs are efficient.

\section{Discussion}

Research on the development of Indonesian language teaching materials based on scientific learning to foster creativity and innovation of students in Primary School Teacher Study Program, used this type of research and development by using the Four-D Development Model (Thiagarajan, et al, 1974) which consists of four stages, namely define, design, develop, and disseminate. First, in the defining stage the researcher has carried out an analysis activity related to teaching materials to be developed which are adapted to the needs and conditions of the current learning. the second activity was analyzing the conditions and characteristics of special students for those who program Indonesian language subjects for upper class level. The third activity was to study the curriculum and determine what materials 
to be included. The teaching materials were developed based on learning outcomes and semester learning plans. At this stage there were several activities carried out such as determining the indicator, learning objectives, and assignments to be given or included in each subject matter. Second, The design stage is intended to design scientific-based Indonesian teaching materials in Indonesian language courses at the PGSD FIP UNM study program. At this stage the researcher has carried out the TIM consolidation activity by routinely conducting meetings to discuss the design of the teaching material to be developed. Then the next activity is the selection of sources that become the reference in research activities based on the results of meetings with the research team and the third activity is to formulate scientific-based teaching materials while prioritizing the feasibility and appearance of teaching materials as attractive as possible.Third, in the development stage, the teaching material has been revised based on the results of the prototype- 1 analysis, input from experts and practitioners as well as the analysis results on learning activities. Furthermore, the results of improvements in field trials in the development phase produce prototype-3, then prototype- 3 devices are socialized to produce the final prototype.

\section{Results of Analysis on Feasibility of Teaching Materials}

The results of the analysis on the feasibility level of teaching materials have been made after being examined and viewed by experts. The average value of the validity level of Teaching Materials is $=3.9$. Thus, it can be concluded that the average value is included in the category of "Valid". In other words, it is included in the range $(3.5 \leq \bar{V}<4,5)$. If viewed from all aspects of the criteria, the teaching material is declared to meet valid category.

\section{Results of Analysis on the Effectiveness of Teaching Materials}

Based on data about average percentage of students' responses from three observers, information was obtained that students were more active in doing activities in the first category, namely actively listening and paying attention to lecturers' explanations. Then followed by the seventh and fifth categories in a row namely responding to friends' answers or expressing opinions or ideas and compare answers and discuss in their cooperative groups. This is because the learning model used is a cooperative learning model so students are required to work together in groups and exchange ideas to solve problems in daily life. In addition, the format of teaching materials is equipped with interactive questions to make students interested and motivated in the learning process. The analysis results of the observations on the implementation of the teaching materials can be explained as follows: Overall, the observer generally observed that the learning material used are "available" and the learning devices or teaching materials are also implemented or used fairly well and in fact it can be said to be quite perfect. Overall, observers generally consider that the learning tools used are "available" and teaching materials are also implemented or used quite well and can even be said to be quite perfect.

\section{Results of Analysis on Efficiency Levels of Teaching Materials Based on Student Achievement Review.}

Descriptive Statistics analysis results and their representation in the activities of developing Indonesian language teaching materials have shown that these teaching materials are very effective for use in lectures. This shows that the average score of students from pretest to post-test has increased (from 2.75 to 3.50). The average score of students in the pre-test is 2.75 with a standard deviation of 0.94 , a minimum value of $0(\mathrm{E})$ and a maximum value of 4 (A) of an ideal score of 4 . Meanwhile, the average score of students at posttest is 3,50 with a 
standard deviation of 0.33912 , a minimum value of 2.8 and a maximum of 3.8 from an ideal score of 4 . The increase shows that teaching materials that have been prepared in Indonesian language courses that are used in lectures on PGSD study programs are efficient.

\section{Conclusion}

Based on the results of research and discussion, it can be concluded that: 1) Development of students' book, beginning with studying the substance of Indonesian language teachin in Higher Education. The next steps are modifying and adapting the Thiagarajan 4D model (Define, Design, Develop and Desiminate). After that, validation is done through expert opinion and expert judgment and analysis of trial data, then finalization; 2) Developing Indonesian language teaching materials based on scientific learning to foster creativity and innovation of PGSD students in UNM Watampone is in the category of very good; 3) The effectiveness level of Indonesian language education teaching materials based on scientific learning to foster creativity and innovation of PGSD students in UNM Watampone is in the very effective category to be used.

\section{Acknowledgement}

The research was supported by the Non-tax State Revenue fund (PNBP 2018) in State University of Makassar. We would like to show our gratitude to the director of Graduate Program State University of Makassar for the support. We thank to the Chief of LP2M who provided research permit. We are also immensely grateful to Dr. Rukayah M.Pd for the cooperation in the research and also to PGSD students who have participated in this research.

\section{Reference}

Dell'Olio, D. J. M. M., \& Donk, D. T. (2007). Models of Teaching: Connecting Student Learning with Standards. Thousand Oaks: SAGE Publications. Retrieved from http://public.eblib.com/choice/publicfullrecord.aspx?p=996882

Kurnianita, E. (n.d.). Upaya Meningkatkan Kemampuan Kerjasama, Keaktifan Dan Hasil Belajar Siswa Menggunakan Model Cooperative Learning Tipe Co-Op Co-Op Pada Mata Pelajaran Ips Siswa Kelas VIII G SMP Negeri 1 Minggir Sleman, 16.

Muhson, A. (2011). Portofolio-Based Instruction Sebagai Model Pembelajaran, 8, 11.

Nurfitasari, Y., \& Suryandari, K. C. (n.d.). Analisis Kemampuan Kerjasama Siswa Dalam Pembelajaran Ipa (Studi Deskriptif Pada Siswa Kelas V Sd Negeri 4 Kutosari Tahun Ajaran 2017/2018), 7.

Pratiwi, I. A. (2015). Pengembangan Model Kolaborasi Jigsaw Role Playing Sebagai Upaya Peningkatan Kemampuan Bekerjasama Siswa Kelas V SD Pada Pelajaran IPS. JURNAL KONSELING GUSJIGANG, 1(2). https://doi.org/10.24176/jkg.v1i2.411

Pratiwi, I. A., Ardianti, S. D., \& Kanzunnudin, M. (2018). Peningkatan Kemampuan Kerjasama Melalui Model Project Based Learning (Pjbl) Berbantuan Metode Edutainment Pada Mata Pelajaran Ilmu Pengetahuan Sosial. Refleksi Edukatika : Jurnal Ilmiah Kependidikan, 8(2). https://doi.org/10.24176/re.v8i2.2357

Sadikin, A., Aina, M., \& Hakim, N. (2016). Penerapan Asesmen Berbasis Portofolio Dan Jurnal Belajar Untuk Meningkatkan Kemampuan Metakognitif Dan Motivasi Belajar Mahasiswa Pada Mata Kuliah Perencanaan Pengajaran Biologi, 12.

Shamir Inbal, T., \& Blau, I. (2016). Digital Literacy Skills And The Challenge Of Collaborative Culture In Higher Education: From Individual Psychological Ownership To Co-Ownership (pp. 9012-9013). Presented at the International Conference on 
Education and New Learning Technologies, Barcelona, Spain. https://doi.org/10.21125/edulearn.2016.0096

Taniredja, T. (2012). Model-Model Pembelajaran Inovatif. Bandung: Alfabeta.

Wulandari, B., Arifin, F., \& Irmawati, D. (2015). Peningkatan Kemampuan Kerjasama dalam Tim Melalui Pembelajaran Berbasis Lesson Study. Jurnal Electronics, Informatics, and Vocational Education (ELINVO), 1, 8.

Yulianti, S. D., Djatmika, E. T., \& Susanto, A. (2016). Pendidikan Karakter Kerja Sama Dalam Pembelajaran Siswa Sekolah Dasar Pada Kurikulum 2013. Jurnal Teori dan Praksis Pembelajaran IPS, 1(1), 33-38. https://doi.org/10.17977/um022v1i12016p033

Zahra, S., Tandi, H. Y., \& Ratna, Y. (n.d.). Pengaruh Model Pembelajaran Berbasis Portofolio Terhadap Hasil Belajar Siswa Kelas V Pada Mata Pelajaran IPA SDN No 3 Parigi. Elementary School of Education E-Journal 8, 8(1), 1-15. 